\title{
Boko Haram Insurgence in Borno State, North-Eastern Nigeria and the Emergence of Internally Displaced Persons (IDPs) Camps in Maiduguri Metropolis, 2011 - 2017
}

\author{
Idris Abubakar Zakari* \\ Department of History Bayero University, Kano, Kano State, Nigeria
}

DOI: $10.36348 /$ sjhss.2019.v04i11.003

| Received: 30.10.2019 | Accepted: 06.11.2019 | Published: 18.11.2019

*Corresponding author: Idris Abubakar Zakari

Abstract

Internally Displaced persons (IDPs) camps are tents or buildings constructed or erected by the government or nongovernmental organizations (NGOs) to accommodate people who have been forced to flee or leave their houses or places of habitual residence. In other words IDPS are centers that harbour those people who have been forced to abscond their abodes and places of habitation. These people who have not crossed an internationally recognized line that divide or separates the state but remain within the country's border may be victims of inhumanity of man against man, victims of violence, confrontation, armed conflicts violations of human rights, terrorism, riots, communal clashes, religious conflict and natural and human made disasters. To avoid the effects of the above and fears of further attacks or revenge by rural groups or disputants which people have to flee or move to another safe place. In most cases, the homes or houses and places of work of these people are demolished or destroyed without any alternative thus, making them vulnerable and in dire need of assistance. In response to their plight government may construct camps to among others provide them with shelter, basic needs such as food, cloth, water, conselled them, care for them and above all assist them to overcome the emotional traumatization that are usually associated with such a nasty experience. It is against this background that this paper will illuminate the Boko Haram insurgence in Borno State, North eastern Nigeria and its role in the emergences of internally displaced persons (IDPs) camps in Maiduguri Metropolis within the context period, $2011-2017$.

Keywords: Boko Haram, Internally Displaced persons (IDPs) Camps, Maiduguri Metropolis.

Copyright @ 2019: This is an open-access article distributed under the terms of the Creative Commons Attribution license which permits unrestricted use, distribution, and reproduction in any medium for non-commercial use (NonCommercial, or CC-BY-NC) provided the original author and source are credited.

\section{INTRODUCTION}

In 2009 a radical revolutionary Islamic movement known as Jama 'atu Ahl Sunna Lidda'awati Wal Jihad - People committed to the propagation of the Prophet Muhammad teachings and jihad (a.k.a) Boko Haram[1] has emerged in Borno State, North-Eastern Nigeria. The group a religio-political organization does not believe in Nigerian constitution, it oppose state corruption and vowed to wage wars against any section of the country, that engage in the murder of innocent Muslims at its embryonic stage, the group was seen as a mere Islamic movement with a radical ideology. But in the course of history and passage of time, the group became a wild fire almost consuming the whole Northern part of Nigeria with its followers boasting to take their battle to the other parts of Nigeria. Indeed, what started as a melodrama where some religious zealots scattered across the country particularly Northern Nigeria did not only threaten the corporate existence of Nigeria as a nation but snow bail into a dangerous group which the security agents for a long time now are battling to manage/dislodge. The activities of the group has not oly led to the loss of lives and properties in the North-Eastern Nigeria but also forced hundreds of thousands of people out of their domicile which made them to become refugees particularly in Borno State, the birth place of sect. To alleviate the sufferings of these down trodden persons, the government of Borno State established the internally displaced persons (IDPs) camps at various locations across the state including the Maiduguri Metropolis which this paper intends to examine. However, to put this paper its proper setting the brief history of Boko Haram as a sect is first discussed.

\section{Boko Haram Sect in History}

Boko Haram is a Hausa and Arabic words/terms. While Boko in Hausa language means 'Western education', Haram on the other hand is an Arabic word/term which figuratively means 'sins' and 
literally means forbidden. Boko Haram therefore is translated as Western education sacrilege or western education is a $\sin [2]$.

The date for the emergence of this sect/group in Nigeria appears conflicting. While some scholars trace the foundation/emergence of the group or sect to the period of the conquest of the Sokoto caliphate of Northern Nigeria which occasioned the introduction of Western education in the region, others trace the emergence of the group to the 60s[3]. Besides, there is another group that traced the emergence of Boko Haram sect/group to 1995. This view corroborates an assertion credited to a scholar:

The history of this radical Islamic sect under the leadership of Muhammad Yusuf is not new to the followers of Nigerian history.

The group has been in existence in the country for about 14 years under the searchlight of security operatives with different names.

Security report has it that the sect has been in existence in the country as far back as 1995. Security agents have been monitoring their activities and containing them for years even though they change their names, and identity, their doctrines, beliefs and ideas of intolerance remained unchanged [4].

Whatever may be the variations among scholars as regard to the date of the emergence of Boko Haram sect/group in Nigeria, the group/sect was launched in Maiduguri, the Borno State capital in 2002[5] with Malam Muhammad Yusuf as its leader. The group became popular in 2003 when Nigerian government was preparing to host two international events i.e the all African games and the meetings of Common Wealth Heads of Government. It was in this period that the Nigerian security agents discovered $\mathrm{Al}$ Qaeda cell in the country [6].

In 2004, the Boko Haram sect moved to Kanama in Yusufari local government area in the present day Yobe State where they set up a base called Afghanistan. The group/sect which was founded as an indigenous group in the year 2009 metamorphoses to a Salafist Jihad. Their school of thought considers anything western as an aberration or completely unIslamic. The group views the influence of western culture on Islamic society as religious weakness and any member who fight for the course of Islamic Sharia State by destroying secular State formation and government, Al-janna - (paradise) would be his permanent abode [8].

Boko Haram largely conducted its operation in Maiduguri, Borno State capital between 2002 - 2008 peacefully which made the government of the day to repeatedly ignore the warning about the increasing militant nature of the organization including that of military officer [9]. However, in 2009 things changed based on the security report that the group members had embarked on stocking arms; this made the government to start investigating the activities of the group [10].

It is however, pertinent to note that, the clash between the group/sect and the security agents called operation flush in Maiduguri metropolis on $11^{\text {th }} \mathrm{July}$, 2009 in which 17 members were killed; this dealt a devasting blow to the sect and its leader Muhammad Yusuf vowed to avenge the killing at appropriate time. The $30^{\text {th }}$ July 2009 killing of seven hundred (700) members of the group in Bauchi produced only minimal hostilities [11].

However, the killing of Malam Muhammad Yusuf the sect leader on $30^{\text {th }}$ or $31^{\text {st }}$ July, 2009 and the killing and arrest of many members neither weakened the strength nor exterminate the sect but triggered violent attacks from the group on regular basis on the mosques, churches, security personnels and government establishments[12].

In July 2010, the sect regrouped under a new leader Malam Abubakar Shekau. Shekau was the second in command to Muhammad Yusuf who died in police custody. Under Abubakar Shekau, the group continues to launch violent attacks on several spots not only in Borno State and Northern Nigeria but Nigeria as a whole [13].

Prior to $2^{\text {nd }}$ quarter of 2011, Boko Haram was not a terror group, but following the bombing of the United Nations Organization Headquarters in Abuja, on $26^{\text {th }}$ August, 2011, the sect was declared a terrorist [14]. In 2013, Boko Haram occupied not only most parts of Borno State but also some parts of the North-Eastern Nigeria, this forced the government of the period to declare a state of emergency in states such as Adamawa, Borno and Yobe States considered to be most affected in the history of Boko Haram hostilities in the North-Eastern geo-political zone of Nigeria [15]. It is argued that, the dramatic escalation of violence by this sect in 2014 result in wide spread hostilities to the neighbouring Cameroon, Chad and Niger, thus making the crises to assume the status of a regional conflict [16].

One of the most deadly attacks of Boko Haram sect which drew the attention of both national and international communities was the capture and bondage of 250 girls from their school, Chibok, Borno State on $14^{\text {th }}$ April, 2014. The Chibok Girls abduction by the sect though some of the girls have regained their freedom tills this moment remains one of the top concerns of the international communities [17]. 
It is worthy of note that at the beginning of 2015, Boko Haram sect was controlling 20 local government areas of Borno State (a territory the size of Belguim) [18]. The group however as a result of coalition were forced to retreat to Sambisa forest where they remained up to the capture of Camp Zero the sects strong hold in the forest by Nigeria Army on 28 December, 2016[19].

Nevertheless, from 2009 - 2015, the sect had not only attacked and killed several political and religious leaders or their families especially those who openly condemned or criticized their activities but also destroyed properties worth millions of naira[20].

\section{Chronicles of Boko Haram's Insurgence in Borno State from 2011 - 2017}

- $\quad 28^{\text {th }}$ January, 2011 - The governorship candidate of Borno State under All Nigeria People's Party (ANPP), Alhaji Modu Fannami Gubio and six others at Lawan Bukar Ward, Maiduguri were killed.

- $\quad 7^{\text {th }}$ April, 2011 - An explosion hit a polling booth at Unguwar Doki, Maiduguri, Borno State injuring more than ten people.

- $\quad 15^{\text {th }}$ April, 2011 - Youth riding on a motorcycle threw a locally made bomb into the premises of the Maiduguri office of the INEC.

- $\quad 25^{\text {th }}$ April, 2011 - Three bomb blasts rip through Tudu Palace Hotel and Kano Motor Park, Maiduguri.

- $\quad 4^{\text {th }}$ May, 2011 - Killed a prison warder at Maiduguri prison in Kashim Ibrahim way.

- $\quad 5^{\text {th }}$ May, 2011 - Shot an officer on duty at Maiduguri Government House, Umar Shehu at his Abuja Talakawa residence of Maisandani ward killing a 13 year old boy and injured another.

- $\quad 9^{\text {th }}$ May, 2011 - Killed two Islamic clerics, Sheikh Goni Tijani and Alhaji Abur at their residence in Mairi and Bulabulum wards in Maiduguri.

- $13^{\text {th }}$ May, 2011 - Two people were killed by bomb explosions at London Chinkin, Maiduguri.

- $\quad 15^{\text {th }}$ May, 2011 - Planted bomb at Lagos Street, Maiduguri, which injured two soldiers and three policemen. A policeman was also injured the same day in the city.

- $\quad 31^{\text {st }}$ July, 2011 - Killed Shehu of Bomo's brother Alhaji Abba Anas Garba El- Kanemi.

- $\quad 1^{\text {st }}$ June, 2011 - Five people were killed during attack in police station in Maiduguri [21].

From the above analyses of these hostilities it is evident that from 2009 - 2012, most of the activities/attacks of the group were confined to Maiduguri metropolis, where they launched a series of attacks on the metropolis, setting several mosques, churches, police stations and prisons on fire [22].

However, with the passage of time, Boko Haram's hostilities went beyond Maiduguri metropolis. The group extended their attacks to other areas in Borno State. The reasons for this development as observed were the group's inability to subdue Maiduguri metropolis and bring it under its hegemony [23]. The hostilities of Boko Haram outside Maiduguri metropolis which took place in other parts of Borno State from 2013 to 2016 occurred on the following dates:

- $17^{\text {th }}$ September, 2013 - Boko Haram raided Benisheik. In this raid, members of Boko Haram disguised in military uniform, set up fake check point outside the town and shot all those who tried to flee/escape. At least 142 people were killed and 60 people injured.

- On $14^{\text {th }}$ April, 2014 - Boko Haram attacked Chibok town, and kidnapped more than 250 girls from the ages of 16 to 18 .

- On 13 ${ }^{\text {th }}$ May, 2014 - Hundreds of Boko Haram's militants stormed three villages of Borno State. The villagers resisted, killing more than 200 Boko Haram members.

- On $3^{\text {rd }}-4^{\text {th }}$ June, 2014 - Hundreds of people were killed in raids by Boko Haram's Islamic militants in Borno with death toll at 400 to 500 .

- On $7^{\text {th }}-8^{\text {th }}$ June, 2014 - Suspected Boko Haram militants attacked Garkin Fulani village near Chibok town and kidnapped at least 200 young women.

- On $12^{\text {th }}-18^{\text {th }}$ June, 2014 - Boko Haram attacked and held the village of Kummabza, Bomo State hostage for four days, abducted more than 60 females including children and killed 30 men in the raid.

- On $17^{\text {th }}$ July, 2014 - Boko Haram militants raided Damboa town. By the time the raid ended 66 residents were killed and more than 1,500 were reported to have fled the village.

- In August 2014, Boko Haram militant overran the remote Nigeria border town of Gwoza. It was on the $24^{\text {th }}$ day in that month that the sect's leader Abubakar Shekau announced Gwoza as part of Islamic caliphate.

- In September, 20014 - Boko Haram militants invaded and captured the second largest town in Borno State, Bama. In this raid, 55 people in the town were reported to have been killed by the sect.

- In November 13, 2014 - Boko Haram attacked Chibok town and brought it under their control.

- In November 16, 2014, it was reported that 20 towns and villages have were brought under the control of Boko Haram.

- In December 20, 2014, the Boko Haram attacked Gamsuri, over 30 people killed and kidnapped over 100 women and children.

- In January 3, 2015, Boko Haram militant attacked 
Baga and Doron Baga towns, Borno State. It was said that from 3-7 January, 2015, Boko Haram shot indiscriminately from armoured vehicles and set over 2,200 building in Baga and 3,100 in Doron Baga on fire.

- In January 25, 2015, the Boko Haram militants attacked and captured Monguno including a nearby military base.

- In February 20, 2015, the militant group i.e. Boko Haram invaded and captured Gamboru.

- On the $1^{\text {st }}$ and $2^{\text {nd }}$ July, 2015 - Boko Haram sect launched a multiple attacks on mosques at Kukawa, leaving forty eight people including boys dead.

- On $15^{\text {th }}$ July, 2015, they attacked Mainek village in Kaga local government in which 30 people were killed by the group.

- On $16^{\text {th }}$ July, 2015, the militants attacked Warsala village in Borno State.

- In September 20, 2015 there were series of bombing in Maiduguri, Munguno and other places in Borno State.

- On $21^{\text {st }}$ October, 2015, Nganzai the fleeing militant shot at four cars killing the passengers burnt and looted the nearby village.

- In October $23^{\text {rd }}, 2015$ suicide bombing occurred in a predawn attack at a mosque in Maiduguri.

- On $25^{\text {th }}$ December, 2015 explosives detonated in mosque in Maiduguri Borno State killing 25 and 65 wounded.

- On the same day $25^{\text {th }}$ December, 2015 - Boko Haram set fire on the village of Kimba killing at least 14 people.

- On $27^{\text {th }}$ December, 2015 gun men with RPGS battled with troops for two hours in Aldowari village in the outskirts of Maiduguri metropolis.

- On $28^{\text {th }}$ December, 2015 there was bombing at a nearby mosque in the outskirt of Maiduguri leaving at least 20 people dead. ${ }^{24}$

- $\quad 6^{\text {th }}$ January 2016, a suicide bomber blew him near a market in Sambisa forest, 5 people were killed.

- $\quad 13^{\text {th }}$ January 2016, a suicide bomber blew himself inside a mosque at Kouyape, 12 people were killed and 1 person wounded.

- $\quad 27^{\text {th }}$ January 2016, Boko Haram attacked Villages in Dalori area outskirts of Maiduguri town 100 people were killed and 2015 wounded.

- $\quad 30^{\text {th }}$ January 2016, an attack on Dalori Village 4 Kilometres away from Maiduguri town, 86 people were killed and unknown number wounded.

- $10^{\text {th }}$ February 2016, two female suicide bombers sneaked into an internally displaced persons (IDPs) Camp at Dikwa and detonated themselves 60 people were killed and 78 wounded.

- $12^{\text {th }}$ February 2016, Boko Haram attacked a Village near Ka Chifa, 8 people were killed.

- $13^{\text {th }}$ February 2016, Boko Haram attached Yakshari Village 22 people were killed.

- $16^{\text {th }}$ March 2016, Boko Haram attacked Umarori
Village outskirts of Maiduguri town, three female suicide bombers detonated bombs, 22 people were killed while 18 wounded.

- $26^{\text {th }}$ March 2016, Boko Haram raids a remote Village of Tunpun and killed 4 people.

- $8^{\text {th }}$ April, 2016, supposed attacked neutralization of Boko Haram suicide bombers, 3 people were injured.

- $20^{\text {th }}$ April 2016, bombing took place near border of Nigeria with Cameroon 7-8 people were killed several others injured.

- $24^{\text {th }}$ April 2016, Boko Haram attacked Alau Village, 30 people were killed.

- $11^{\text {th }}$ May 2016, Boko Haram attacked Sulaimanti Community outskirts of Maiduguri town; unknown number of deaths was recorded.

- $12^{\text {th }}$ May 2016, a stoppage and explosion suicide bomber, 8 people were killed.

- $\quad 29^{\text {th }}$ May 2016, explosion before military target in Biu town, 5 people were killed 2 wounded.

- $4^{\text {th }}$ July 2016, attack on (IDPs) Camps in Maiduguri, 2 suicide bombers were killed and 2 people injured.

- $8^{\text {th }}$ July 2016, a Mosque in Borno was attacked by suicide bombers, 9 people were killed and 12 injured.

- $11^{\text {th }}$ October 2016, an explosion attack on Maiduguri, 18 persons were killed.

- $\quad 29^{\text {th }}$ October 2016, two suicide bombers detonated their bombs in Maiduguri, 8 people were killed.

- $\quad 1^{\text {st }}$ November 2016, a car bomb explosion near military check point at Gubio 9 people were killed.

- $5^{\text {th }}$ November 2016, Army had a gun battle with Boko Haram 7 people were killed.

- $\quad 22^{\text {nd }}$ November 2016, Boko Haram attacked Military post next to the Kolafata Camp, 6 people were killed.

- $23^{\text {rd }}$ November 2016, suicide bomber killed 6 people in Maiduguri town

- $\quad 9^{\text {th }}$ December 2016, apprehension and explosion of suicide bomber before striking in Maiduguri town.

- $11^{\text {th }}$ December 2016 explosive attack by 2 suicide bombers in Maiduguri town 3 people were killed.

- $13^{\text {th }}$ December 2016, Boko Haram attacked a military base at Kamuyi Village Borno State leaving scores dead.

- $10^{\text {th }}$ January 2017, two female suicide bombers disguised as visitors and detonated bombs at Kalari area Maiduguri, 5 people were killed.

- $13^{\text {th }}$ January 2017, Nigeria Army foiled an attack on their position by Boko Haram militias in Kangarwa Village Borno State 3 soldiers were killed 27 injured and 14 militants were killed.

- $14^{\text {th }}$ January 2017, Boko Haram carried out roadside bombing explosions in Maiduguri, 5 soldiers and 10 attackers were killed.

- $16^{\text {th }}$ January 2017, two teenage suicide bombers blew themselves in a Mosque University of Maiduguri, 3 people were killed. 
- $19^{\text {th }}$ January 2017, twin bomb blast rocks Mun Garage, Maiduguri town, 11 persons were killed.

- $\quad 23^{\text {rd }}$ January 2017 , accidentally military bombing of internally displaced persons (IDPs) Camps in Borno State 234 people killed.

- $17^{\text {th }}$ February 2017, suicide bombers invaded Maiduguri town, 11 persons killed[24]

These regular attacks, loss of lives damage of properties and infrastructure on the account of bombing, on conquest and sack of many towns and villages between the periods of 2013 - 2014 in Borno State by Boko Haram sect, have normally not only created fears in the minds of the people within the state but also had caused many people of Borno state to flee their towns and villages [25].

The scourge of Boko Haram phenomenon has indeed forced many people from different parts of Borno State to move in droves from their original place of habitation. It is said that while some of the people in Borno State as a result of this violent attacks migrate to other areas outside Borno State in other parts of Nigeria, others for the fear of their lives migrated enmass into Maiduguri metropolis, the Borno State capital which was considered safe, and remains unconquered by Boko Haram group in their endeavour to establish an Islamic state.

In essence, the consequences of this forceful migration into Maiduguri metropolis as a result of these violent attacks from Boko Haram is that, amongst others swelled the population of Maiduguri which as observed jumped from 2 million in 2012 to 3 million in 2014[26], and induced a huge internal population displacement that led to establishment of Internally Displaced Persons (IDPs) camps in Maiduguri metropolis.

\section{The Emergence of Internally Displaced Persons (IDPs) Camps in Maiduguri Metropolis 2011-2017}

The violence unleashed by Boko Haram on communities made many people from different parts of Borno State to flee their communities for safety of lives and properties. They moved to Maiduguri town unannounced. These people have not only become refugees but also destitute. The consequences of this development is that it created additional pressure on the available infrastructures such as; hospitals, schools, electricity and shelter. This scenario forced government to establish resettlement camps in Maiduguri metropolis to carter for the displaced persons. These camps spread across the length and breadth of Maiduguri metropolis were not built at once, but in 2017 there were (16) sixteen official and unofficials (IDPs) in Maiduguri metropolis.

However, the names, locations, number of households and number of independent displaced persons (INDs) (IDPs) in Maiduguri metropolis are as at 2017 are as follows:

\begin{tabular}{|l|l|l|l|l|l|}
\hline S/N & SITE ID & \multicolumn{1}{|c|}{ SITE NAME } & \multicolumn{1}{|c|}{ WARD NAME } & No.HHS & No. OF INDS \\
\hline 1 & BOS001 & NYSC Camp & Maisandari & 727 & 4730 \\
\hline 2 & BOS005 & Arabic Teacher's College & Maisandari & 978 & 6172 \\
\hline 3 & BOS010 & Bakasi Camp & Maisandari & 1842 & 12880 \\
\hline 4 & BOS012 & EYN Camp & Lamisula/J Abba Mari & 222 & 1522 \\
\hline 5 & BOS013 & MOGCOLIS Camp & Mafoni & 504 & 2520 \\
\hline 6 & BOS014 & Teachers Village & Bolori I & 1242 & 8688 \\
\hline 7 & BOS019 & CAN Catholic Sectariat & Maisandari & 38 & 219 \\
\hline 8 & BOS024 & Garba Buzu Quarter & Bolori I & 518 & 4128 \\
\hline 9 & BOS025 & Sabon Gari Buzu Camp & Bolori I & 106 & 735 \\
\hline 10 & BOS037 & Kusheri I & Maisandari & 45 & 125 \\
\hline 11 & BOS038 & Kusheri II & Maisandari & 27 & 130 \\
\hline 12 & BOS039 & Wulaki Dujima & Lamisula/J Abba Mari & 20 & 114 \\
\hline 13 & BOS040 & Shuwari & Lamisula/J Abba Mari & 96 & 384 \\
\hline 14 & BOS041 & Suleimanti & Maisandari & 60 & 780 \\
\hline 15 & BOS042 & Federal Low Cost Chezcoan & Bolori I & 102 & 303 \\
\hline 16 & BOS043 & Living Faith Church & Bolori I & 10 & 62 \\
\hline & & & Total & $\mathbf{6 , 6 3 7}$ & $\mathbf{4 3 , 5 9 1}$ \\
\hline
\end{tabular}

Source: M. Goni; 'The NGO's and Humanitarian services in Internally Displaced Persons (IDP) camps in Maiduguri Town, 20132016', B.A. Project, Department of History, University of Maiduguri, 2016, p. 30.

The purpose of the establishment of these IDP camps in Maiduguri metropolis is as a result of displacement of the people by Boko Haram attacks was to use the camps not only to protect and assist the uprooted population but also to provide them with shelter and other social amenities[27].
Though in these Camps, the displaced persons enjoy free feeding, medical care, cloth, water and other basic needs, the camps however, in the periods examined above were pregnant with problems. 


\section{Problems/Challenges of Internally Displaced Persons (IDPs) Camps in Maiduguri Metropolis}

The problems or rather challenge facing the Internally Displaced Persons (IDPs) Camps located in Maiduguri metropolis are numerous. These challenges or problems however can best be understood under the following.

First, one of the numerous problems faced by the Internally Displaced Persons (IDPs) Camps in Maiduguri Metropolis between 2011 - 2017 is lack of adequate and safe shelter. It is argued that most of these (IDPs) live in makeshifts such as schools, sports centres, mosques, churches etc. In schools, many of the displaced live in classrooms that have no windows and doors and sleep on bare floors and are exposed to harsh weather condition. As such, many migrants or displaced prefer to take refuge in the houses of their families or relatives, and friends. Those who do not have relations or friend in Maiduguri town pay for temporary accommodation or forced to take refuge in abandoned buildings in the metropolis [28].

Second, in the IDP camps in Maiduguri metropolis, there was also the problem of inability to have access to food and other household basic necessities. They could not access their sources of revenue as they flee. The assistance in the camps when provided is in short supply or grossly inadequate. The destruction of property, crops and of food stuffs at the time of their displacement pose food security among the (IDPs). During the early phases of displacement state government and donor agencies use to provide basic food items through (SEMA) but are often quickly exhausted, thus making the displaced to spend days without food. This development force them to turn seek for help from the host for basic needs. It was as a result of this food shortage that made some hundreds of Women (IDPs) in Maiduguri metropolis to embarked on a peaceful demonstration for alleged shortage of food supply or diversion by officials i.e. SEMA on August 29, 2017[29].

Thirdly, in the area of health care delivery the IDP Camps in Maiduguri Metropolis have little access to health services. Lack of access to health facilities cis of particular concern, noting that the majority of these camps are inhabited by women and children. They lived in unhygienic condition which exposed them to infectious and contagious diseases such as cholera etc [30]. The outbreak of this disease as a result of to poor sanitary condition and gross inadequate provision of sanitary items to the (IDPs) camps led to the dead of more than 20 Internally Displaced Persons (IDPs) in Maiduguri Metropolis [31]. In these camps, the displaced have limited access to portable water and inadequate sanitation thus lead to a decline in health and hygiene among the (IDPs) camps. The lack of water and sanitation facilities has raised serious concerns about the outbreak of diseases. Public latrines, in the camp like the school setting is often non-existent or conducive [32]. Defecation and disposal of children's waste are done in the open. This open defecation gives rise to health and security challenges and dignity issues particularly for women and girls and these created tensions in the camps. Apart from this, there exist environmental problem. Among the displaced households the hygiene is very poor as a result of overcrowd situation and shortage of water and other materials. This is of particular concern to women and teenagers who face the challenge of maintaining personal (menstruation) hygiene [34].

Forth, in the area of education, the Internally Displaced Persons in the period examined find it difficult to have access to Education. With many (IDPs) Camps in Borno State has made it impossible for the children of the displaced to pursue their education [35]. Since 2012 some schools in Maiduguri Metropolis remained closed. The closure has drastically reduced access to education. In April, 2013, 14 schools in Maiduguri Metropolis's were destroyed by unidentified gunmen and by March 2014 all state schools in Borno State, Maiduguri Metropolis inclusive were closed. This development made it difficult for the Internally Displaced Persons to send their children to school to acquire knowledge pursue education. Attendance rates declined drastically. The abduction of students in some (IDPs) camps outside Maiduguri Metropolis made some parents in Maiduguri IDP camps to be wary of sending their children to schools. Even in comparative safety of Maiduguri metropolis, parents in these camps tend to priorities basic needs such as shelter and food over education. On the other hand, those parents in (IDP) camps who are interested in the education of their children were often refused attendance by their host community's schools claiming that they do not have the facilities or staff to take on more students. Though some areas in Maiduguri IDPs camps have large distribution centres with schools supported by the UN Children Fund (UNICEF), the coverage of such programme is unknown[36].

Fifth, there was increase in social vices particularly prostitution, in the Internally Displaced Persons Camps in Maiduguri Metropolis. In these camps unrestrained sexual activities reign supreme. There are reported cases of rampant rapes in the camps. These rapes in most cases are by women. The consequences of this unrestrained sexual behaviours or illicit sexual behaviours is that not only female girls are being put into a family way but also an increasing in sexually transmitted diseases such as HIV/AIDs. In these camps state government do not provide condom to the (IDPs) camps. Besides, many displaced persons in the camps do not have money to buy the condoms. This has contributed significantly to the increase in the number of people infected with HIV/AIDs and other sexual transmitted diseases in these camps [37]. 
Sixth, beside the above there was the proliferation of hard drugs in camps in Maiduguri metropolis. This problem though new in the camp, it is reported that before the rise of insurgency in Maiduguri metropolis Borno state in general is known as a hub for illicit drug trafficking where merchants have links from all over West Africa through Central African Republic to Europe. In these camps, hard drugs like cocaine, heroin, Marijuana harshah etc. were sold to the Internally Displaced Persons. Despite the reported cases of hunger, poverty and malnutrition, in these camps, these people still find money to purchase these illicit drugs in most dire circumstances to satisfy their urge. Though, this act is dangerous, however, according to one source, they use this substance in attempt to attain temporary relief from their problem [38].

Though there are many problems/challenges facing these IDP camps in Maiduguri metropolis, however this is how far we can go in this paper in our analysis of Boko Haram insurgence in Borno State which occasioned the establishment of Internally Displaced Persons (IDP) camps in Maiduguri metropolis.

\section{CONCLUSION}

In this paper, attempts has been made to examine Boko Haram insurgence in Borno State, North-Eastern Nigeria which give rise to the emergence of Internally Displaced Persons (IDP) camps in Maiduguri metropolis. Our analysis so far traces the history of Boko Haram sect and chronicles of the hostilities not only in Maiduguri metropolis but also in Borno State as whole. The paper reveals how Boko Haram violent attacks forced many people from various parts of Borno State to flee and migrate enmass to Maiduguri the Borno State capital. The paper further reveals that additional pressures on Maiduguri metropolis's infrastructure particularly shelter forced the government to establish the Internally Displaced Persons (IDPs) camps which are across the length and breadths of Maiduguri. The paper in addition, reveals that displaced persons were given/provided with food, water and other essential services but according to our analysis in the paper inspite of these, the camps were pregnant with many problems/challenges which include, lack of adequate and safe shelter, the inability of the displaced to exercise their rights as regards to food, and essential household items, poor hygiene, increased cases of sexual transmitted diseases and proliferation of hard drugs such as cocaine, hemp, marijuana, opium etc. To this end, we strongly believe that had it been in the periods examined above, the government of Nigeria has acted and responded swiftly and exterminated the Boko Haram insurgence at its embryonic stage and rebuilt the communities destroyed by Boko Haram sect so that the displaced persons in these Camps can return to their various communities and began a normal life again, the challenges and problems the traumatized faced in IDPs Camps in
Maiduguri Metropolis enumerated in this paper.

\section{REFFERENCE}

1. Boko Haram is an Islamic militant movement which emerged in Borno state, North Eastern Nigeria in the early part of this century. (2011). At the early stage of its formation the group was known as Taliban under the leadership of Mallam Muhammad Yusuf, the sect came to be known as Jama'atu Ahl Sunna Lidda 'awati Wal Jihad- people committed to the propagation of the prophet Muhammad teachings and Jihad (alias) Boko Haram. After the demise of Mallam Muhammad Yusuf in 2009 the group under the leadership of Mallam Abubakar Shekau came to be known as Yaran Mallam- disciples of Mallam. This name at present is used in addition to Boko Haram not only in Borno state, but throughout the North Eastern part of modern Nigeria. For more on the early history of the formation and ideology of this sect see, T.A. Fagge, 'Boko Haram: A militant uprising of a Muslim organization' in S.B. Ahmad and I.K. Abdulsalam (ed.), Resurgent Nigeria issues in Nigeria Intellectual History: A festschrift in Honour of Dahiru Yahaya, University Press, Ibadan, 147-148 and also see M. Isola, 'End of the Road for Boko Haram', Tribune Newspaper, Lagos, 01/07/2009, p.20

2. Alao, D. O., Atere, C. O., \& Alao, O. (2012). Boko-Haram insurgency in Nigeria: The challenges and lessons. Singaporean Journal of Business, Economics and Management Studies, 51(1106), 1-15.

3. Garba , A. (2009). 'Boko Haram sect and Theory of jungle preaching', in New Global Magazine, 2(14), 10/10/2009, p.25.

4. Dabak, N.(2009). 'Boko Haram Uprising: Another Jihad on Christian', The light Bearer Magazine, N.N.; N.N, N.P., 20/07/2009, p. 15

5. Bawa, M.M., \& Idris Z.A.(2017).' The proliferation of small Arms and Light Weapons in the North Eastern Nigeria and The rise of Boko Haram', a paper presented at the first international conference on Defence, Security, Economy and Development in Nigeria, organized by Department of History and War Studies, Nigeria Defence Academy Kaduna on $26^{\text {th }}$ March to $1^{\text {st }}$ April, 2017 at Ejoor Hal post Graduate school, Ribadu campus, old site, Nigeria Defence Academy, Kaduna.

6. Atim, T. (2014). 'The State and Sectarian violence in North-Eastern Nigeria: A study of Boko Haram Radicalism', in P. Bwaya and A.R. Audu (ed), Northern Region and Challenges of Development, Al- Mishadan, Makurdi, Benue state, 353

7. Boko Haram, http://nees.bbc.c.o.uk./1/hi/programme, August 
2009,

8. Tom Uhia, O.(2016). 'Boko Haram: The inside story;, Power steering Magazine, N.V., N.N., September, 35.

9. Uhia, Boko Haram: The Inside Story... p.35

10. Uhia, Boko Haram: The Inside Story... p.35

11. Ngige, C.V.(2011). 'The media and Boko Haram insurgency in Nigeria; A content Analysis and review', international journal of peace and conflict studies, 3, 60

12. Uhia, Boko Haram: The Inside Story... p.35

13. Olasile, R.S.(2015). 'Boko Haram: The menance of small Arms and Light

proliferation in Nigeria', International journal of Education and Research, N.V., Mjgy, USA, 30

14. Nossiter, A.(2015). 'Sucide Bomber Attacks UN Building in Nigeria', New York Times www.nytimes.com.2011/08/27, world Africa 27 Nigeria html. page wanted=all $>26$ August 2011 web 9. January 2015 Retrieved.

15. Awodula, A., \& Ayuba, C. (2015). 'Terrorism in Nigeria; The case of Boko Haram', Journal of social science, 6(52), Rome, Italy, 253

16. Awodula and Ayuba, 'Terrorism in Nigeria' ... p. 253

17. Ibrahim, J. 'Chibok, Sambisa and Struggle for liberation', Daily Trust Newspaper, Abuja, 30/01/2017, p. 57.

18. Obalonye, I.(2015). 'North Silence is SabotageFG', Daily Sun Newspaper,Lagos, 21/11/2015, p. 25

19. Agila, O. (2017). 'Demystification of Sambisa Forest', Daily Trust Newspaper, Abuja, 30/01/2017, p. 72

20. Uhia, Boko Haram: The Inside Story... p.28

21. Uhia, Boko Haram: The Inside Story... p. 28

22. Okpaga, A., Ugwu, S. C., \& Eme, O. I. (2012). Activities of Boko Haram and insecurity question in Nigeria. Oman Chapter of Arabian Journal of Business and Management Review, 34(965), 1-23.

23. Bukar, M. (2015). 'The impact of Boko Haram insurgence on Maiduguri Town, 2009-2016', B.A. Project, Department of History, University of Maiduguri, 30.

24. Boko Haram Fast Facts', http.//education.com./2014/06/09/world/book.haram-fast-facts-index.html; September 18, 2017, p.4 Retrieved and also see L. Tangshak
Apy.15aRetrRereedamination of Boko Haram Scourage in Nigeria since 2009: Armed conflict/Guerilla warfare; Insurgency or Terrorism? In S. Ibrahim \& (eds).(2017). Defence, Security, Economy and Development in Nigeria. Aboki Publishers, 2, 215-231.

25. 'Campaign of violence', http://en.wiki pedia.org/wiki/Boko-Haram, 1/22/2018, p. 8, Retrieved.

26. M. Bukar, The Impact of Boko Haram Insurgence ... p. 35

27. Goni.(2017). 'The NGO's and Humanitarian serviuesapionisternally displaced persons (IDPs) Camps in Maiduguri Town 2013-2017', B. A. Project, Department of History, University of Maiduguri. 25

28. 'Multiple displacementcrises overshadowed by Boko Haram', w.w.w. internal displacement/org.09/12/2014, p.10 Retrieved

29. Faisal, A. (2017). 'Hunger in Borno IDPs camps', The Politico Magazine, Abuja, 31/07/2017, 7(16):12-17.

30. 'Multiple displacementcrises overshadowed by Boko Harma',www. Internal

displacement/org.09/12/2014, p. 12 Retrieved.

31. Musa, A.,'Boko Haram and Public Health: The Grave Consequences Part (1)', http://www.abusidigu.com.2015, 2

32. Musa, Boko Haram and Public Health ... P. 2

33. 'Multiple Displacement crises overshadowed by Boko Haram', www. Internal displacement/org. 09/12/2014, 3, Retrieved.

34. 'Multiple Displacement crises overshadowed by ...p. 3,

35. Mukhtar, B. (2017). 'The social impact, of Boko Haram Attacks on the people of Maiduguri Town, 20122014', B.A project, Department of History University of Maiduguri, 30

36. Mukhtar, 'The social impact, of Boko Haram Attacks ... p. 33

37. 'What you need to know about the new threat facing Borno IDP camps', http:// ventures Africa. Com/africa-needs-to-seize-the-goldenopportunity-to-promote-economic transformation-helen-hail, 12/26/2017, p.22, Retrieved.

38. What you need to know about the new threat facing Borno IDPs Camps, ... p.22. 